Kajian Jurnalisme

ISSN 2549-0559 (cetak) ISSN 2549-1946 (online)

Volume 01 Nomor 02 Tahun 2018

\title{
Pengunaan Kartun Editorial oleh Poliklitik.com sebagai Bentuk Praktik Jurnalisme Alternatif
}

\author{
Muhammad Afandi dan Aceng Abdullah \\ Program Studi Jurnalistik, Fakultas Ilmu Komunikasi, Universitas Padjadjaran \\ Email: afandicim@gmail.com
}

\begin{abstract}
Abstrak
Penelitian ini bertujuan untuk mengetahui latar belakang pendirian Poliklitik.com, mengetahui manajemen strategi media yang dibangun Poliklitik.com dan mengetahui kualitas jurnalistik yang dihasilkan oleh Poliklitik.com. Analisis strategi ini ditinjau dari aspek internal dan eksternal Poliklitik.com dengan menggunakan kerangka strategi manajemen media Sylvia M. Chan - Olmsted. Untuk menguraikannya, peneliti menggunakan metode penelitian kualitatif dengan pendekatan studi kasus intrinsik. Hasil penelitian ini menunjukan penggunaan kartun editorial sebagai konten utama digunakan oleh Poliklitik.com sebagai bentuk praktik jurnalisme alternatif di tengah dominasi media arus utama. Strategi tersebut diformulasikan berdasarkan aspek eksternal, yakni perkembangan teknologi dan informasi, serta aspek internal yang meliputi sumber daya utama selaku kekuatan utama Poliklitik.com. Simpulan penelitian adalah Poliklitik.com lahir sebagai sebuah media alternatif dengan menggunakan konten kartun editorial agar dapat memberi pengaruh kepada anak muda. Sementara untuk kualitas jurnalistik yang dihasilkan oleh Poliklitik.com sudah memperhatikan kaidah-kaidah jurnalistik namun belum cukup kredibel karena menggunakan teknik agregasi dan kurasi.
\end{abstract}

Kata Kunci: kartun editorial, jurnalisme alternatif, manajemen strategi media, medi baru, studi kasus

\begin{abstract}
This study aims to determine the background of the establishment of Poliklitik.com, knowing the media strategy management that was built by Poliklitik.com and knowing the journalistic quality produced by Poliklitik.com. This strategy analysis is reviewed from the internal and external aspects of Poliklitik.com using the media management strategy framework Sylvia M. Chan-Olmsted. To describe it, researchers used qualitative research methods with intrinsic case study approach. The results of this study show that the use of editorial cartoons as the main content is used by Poliklitik.com as a form of alternative journalism practices in the midst of mainstream media domination. The strategy is formulated based on external aspects, namely the development of technology and information, as well as internal aspects which include the main resources as the main strength of Poliklitik.com. The conclusion of the study is that Poliklitik.com was born as an alternative media by using editorial cartoon content to influence young people. As for the quality of journalism produced by Poliklitik.com, it has taken into elements of journalistic principles but is not credible enough because it uses aggregation and curation techniques.
\end{abstract}

Keywords: editorial cartoons, alternative journalism, media strategy management, new media, case studies

http://jurnal.unpad.ac.id/kajian-jurnalisme 
171 | Kajian Jurnalisme

ISSN 2549-0559 (cetak) ISSN 2549-1946 (online)

Volume 01 Nomor 02 Tahun 2018

\section{Pendahuluan}

Merlyna Lim (2012) menjelaskan dalam The League of Thirteen menyatakan ada 13 kelompok media yang mengontrol semua saham televisi komersial di Indonesia. Ignatius Haryanto dalam media Ownership and its Implications for Journalist an Journalism in Indonesia juga mengungkapkan hal yang cenderung sama. Peneliti senior di Lembaga Studi Pers dan Pembangunan tersebut menyebutkan ada sembilan kelompok yang mengontrol separuh media cetak di Indonesia. https://tirto.id/8-konglomerat-media-di-indonesia-via-jalurmedia-tv-amp-cetak-cEv7 diakses pada rabu 14 Maret 2018

Kemudian Ross Tapsell dalam bukunya yang berjudul Media Power in Indonesia: Oligarchs, citizens, and the Digital Revolution berkesimpulan bahwa perusahaan-perusahaan global belum mendominasi pasar Indonesia dan bukan pendorong utama industri di Indonesia. Sebaliknya, konglomerat media nasional yang punya kuasa dan pengaruh. (https://tirto.id/8konglomerat-media-di-indonesia-via-jalur-media-tv-amp-cetak-cEv7 diakses pada rabu 14 Maret 2018,)
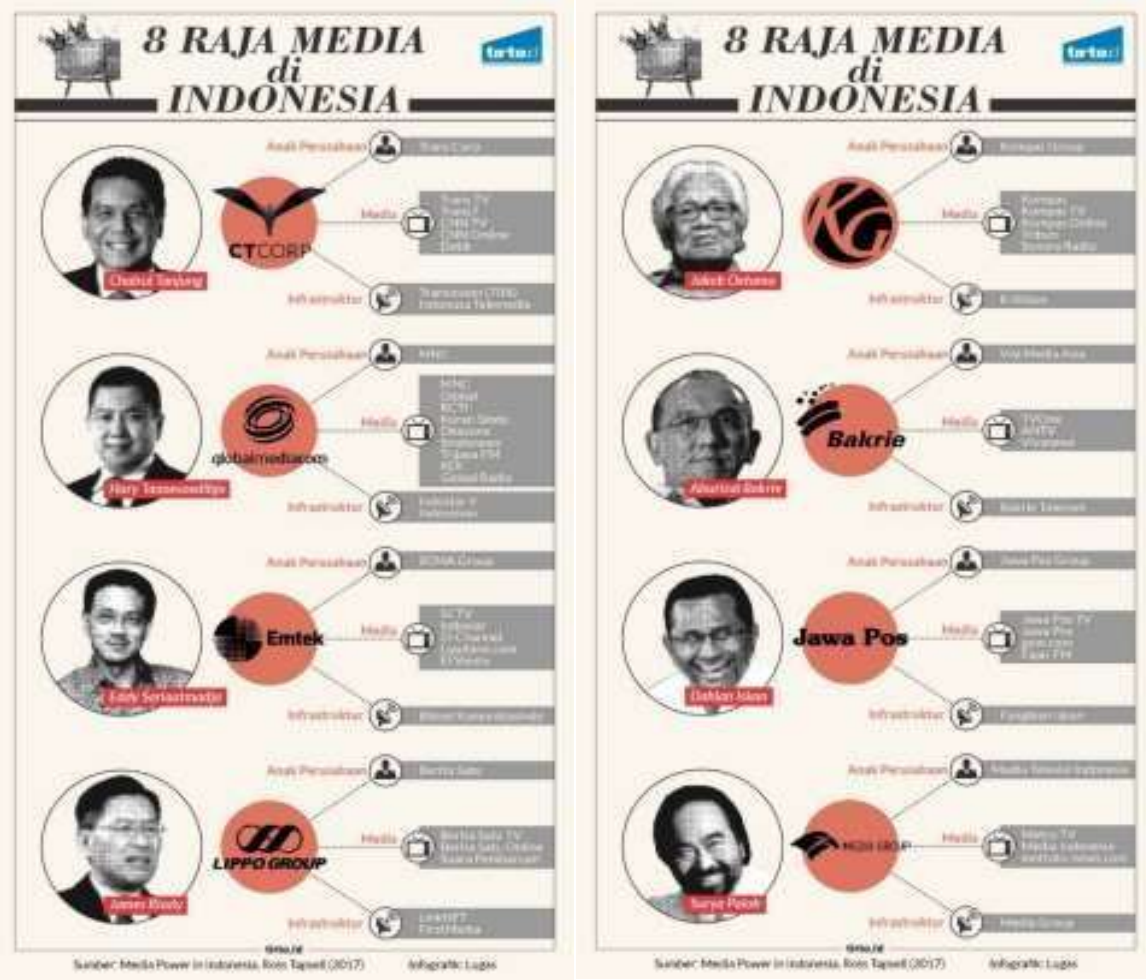

Gambar 1 Peta konglomerasi media massa di Indonesia

Sumber: https://tirto.id/8-konglomerat-media-di-indonesia-via-jalur-media-tv-amp-cetakcEv7 diakses pada rabu 14 Maret 2018, Pukul 20.20 
Kajian Jurnalisme

ISSN 2549-0559 (cetak) ISSN 2549-1946 (online)

Volume 01 Nomor 02 Tahun 2018

Gambaran peta tersebut berpengaruh kepada konten yang sajikan oleh media massa kepada masyarakat luas. Dengan konvergensi media, masyarakat dipaksa menerima infromasi yang sama dari berbagai media yang berbeda namun pada kenyataannya masih dalam satu kelompok media yang sama. Contohnya Trans Crop yang dimiliki oleh Chairul Tanjung, memiliki berbagai media dengan multi platform seperti Trans TV, Trans 7, Trans Vision, CNN Indonesia dan Detik.com. Hal tersebut terjadi menurut Tapsell bukanlah dengan misi menjadi penyalur informasi kepada masyarakat namun murni urusan bisnis. Bahkan Media dengan basis jurnalisme yang kental sekelas Tempo dipertanyakan oleh Tapsell, sebab PT. Tempo Inti Media yang awalnya diletakkan Tapsell di luar garis konglomerasi, namun saat ini sahamnya sudah dimiliki oleh Edwin Soeryadjaya dan Group SCTV yang terafiliasi dengan EMTEK.

Perkembangan internet saat ini juga memaksa media masa konvensional juga berlombalomban bermigrasi ke arah digital. Mereka menyasar pasar internet untuk memperluas bisnis mereka. Pasar digital dalam jaringan dinilai memiliki masa depan cerah dibandingkan media konvensional seperti tv, cetak dan radio. Karena dari data dihimpun dari tekno.kompas.com, survei yang dilakukan oleh Asosiasi Penyelenggara Jaringan Internet Indonesia (APJII) mengungkap bahwa lebih dari setengah penduduk Indonesia kini telah terhubung ke internet. Survei yang dilakukan sepanjang 2016 itu menemukan bahwa 132,7 juta orang Indonesia telah terhubung ke internet. Sementara dilansir dari Liputan6.com, Dewan Pers mencatat ada sekitar 47 ribu media di Indonesia, 44.300 di antaranya media online, sisanya adalah media cetak, televisi, dan radio. ${ }^{3}$ Dari data ini menunjukan lebih dari $90 \%$ media yang ada di Indonesia saat ini merupakan media daring. Masyarakat tersebutlah yang menjadi pasar utama saat ini bagi media arus utama.

Melihat kondisi media di Indonesia saat ini, munculnya beberapa media baru sebagai alternatif sumber informasi selain media arus utama. Salah satunya yakni Poliklitik.com, sebuah portal media dalam jaringan yang menggunakan konten kartun editorial sebagai konten utama. Media ini lahir pada tahun 2015 dengan platform media dalam jaringan dengan memanfaatkan konten kartun editorial. Poliklitik.com diinisiasi oleh Brodo Bilowo yang mengatakan bosan dengan konten dari media arus utama. Dia bermaksud membuat sebuah media dengan konten gambar yang dikemas secara satir dan sarkas, dan berita pendek sebagai faktor pendukung jurnalismenya. Media ini hadir dengan basis internet atau disebut juga media dalam jaringan. Media tersebut menyajikan berita/tajuk harian dalam bentuk karya visual kartun editorial. Media ini menjadikan kartun sebagai kekuatan utama mereka dengan menggunakan platform dalam jaringan sebagai medium distiribusi kepada khalayaknya.

Awal berdirinya Poliklitik.com adalah Brodo Bilowo membuat media ini dan menyampaikan niatnya untuk membuat media berkonsep ilustrasinya kepada seorang temannya yang merupakan CEO Geomedia Group. Kemudian mereka berjodoh dengan Geomedia yang bersedia memfasilitasi urusan domain dan pendanaan. Pada saat itu 
173 | Kajian Jurnalisme

ISSN 2549-0559 (cetak) ISSN 2549-1946 (online)

Volume 01 Nomor 02 Tahun 2018

kontenkonten Poliklitik.com diharapkan dimasukan kedalam Geotimes, yang juga termasuk dalam kelompok usaha media Geomedia Group.

Menurut Brodo Bilowo yang akrab dipanggil Ibod selaku penanggung jawab dari Poliklitik.com, media ini bertujuan menjaring anak-anak muda dengan target 18-24 tahun untuk meningkat kepedulian terhadap keadaan dan kondisi Indonesia. Mengharapkan munculnya anak-anak muda yang kritis dan kepedulian terhadap kebijakan publik. Ia menyatakan bahwa selama ini anak muda terkesan antipati terhadap hal-hal yang berhubungan dengan politik.

"Kita berharap anak muda melihat politik bukan lagi seperti biasanya, ini buat orang tua, apaan nih, kotor, elit aja. Padahal saat kita bayar angkot, makan di warteg itu kan imbas dari sebuah politik. Kita bertujuan agar anak muda kritis akan kebijakan publik. Karena mau tidak mau kita hidup dalam produk-produk kebijakan, besar kecilnya itu berpengaruh kepada kehidupan kita.“

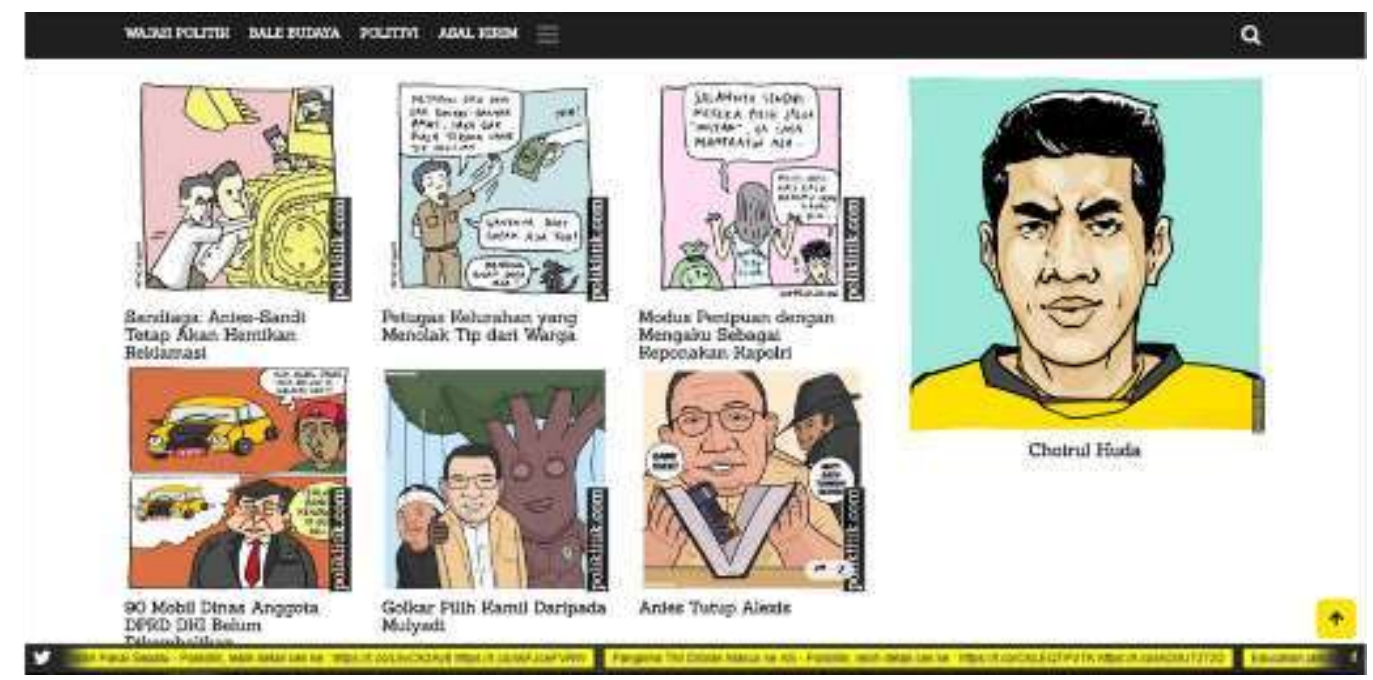

Gambar 2 Tampilan laman website Poliklitik.com Sumber: https://poliklitik.com/

Perbedaan yang paling mencolok dari Poliklitik.com dengan media lainnya adalah konten utama mereka. Konten utama mereka adalah karya visual ilustrasi tentang peristiwa serta fenomena yang sedang hangat saat itu. Media dalam jaringan tersebut berisikan kartun, komik, karikatur dan ilustrasi. Konten tersebut dinilai lebih menarik perhatian kalangan muda. "Mengemas khalayak umum supaya lebih mudah jadi interest, ini apaan sih? Kok komiknya begini banget?" ujar Brodo. Setiap harinya Poliklitik.com memuat minimal satu karya yang disajikan di laman Poliklitik.com dan media sosial mereka.

Konten yang disajikan oleh Poliklitik.com ini berisikan kartun, karikatur, komik strip dan ilustrasi. Kartun, karikatur, komik dan ilustrasi dapat dikategorikan ke dalam salah satu 
bentuk karya junalistik dalam bentuk opini (views). AS Haris Sumadiria dalam Jurnalisme Indonesia, Menulis Berita dan Feature: Panduan Praktis Jurnalis Profesional (2008:6) menyebut berita (news) dan opini (views) saja yang disebut produk jurnalisme. Kelompok berita meliputi berita langsung (straight news), berita menyeluruh (comprehensive news), berita mendalam (depth news), pelaporan mendalam (depth reporting), berita penyelidikan (investigative news), berita khas bercerita (feature news), berita gambar (photo news). Sedangkan kelompok opini meliputi tajuk rencana, karikatur, pojok, artikel, kolom, esai, dan surat pembaca.

Sebenarnya kartun editorial didefenisikan sebagai gambar humor yang menyampaikan opini, sebagai pesan kritik atau komentar pribadi pembuatnya dan lembaga penerbitan pers yang memuatnya, mengenai isu aktual yang berhubungan dengan kepentingan umum. Subagyo (1981: iii) menyatakan akikat kartun editorial sebagai opini, berimplikasi pada kedudukannya dalam klasifikasi artikel penerbitan pers. Isi media massa, biasanya dibedakan menjadi 2 golongan, yakni: (1) berita dan, (2) opini. Dalam unsur opini inilah karikatur (kartun editorial - red) di tempatkan.

Saat peneliti bertanya kepada Brodo Bilowo, mengapa menggunakan kartun sebagai konten utama mereka. Brodo yang sudah lama bergulat di dunia ilustrasi mengatakan bahwa target utama mereka adalah anak muda maka menggunakan cara-cara yang kreatif dan cepat menarik perhatian. Gambar merupakan unsur utama dan menjadi kekuatan dari media ini. Setiap gambar merupakan hasil riset dari peristiwa kemudian dibuat menjadi satu karya visual yang menarik dengan sisipan humor dan pesan sarkas untuk disajikan kepada khalayaknya. Setiap gambar dilengkapi dengan berita yang terverifikasi serta mencantumkan sumber-sumber beritanya.

Sejalan dengan cita-cita Brodo, unsur visual dalam media daring sebenarnya sangatlah penting. Gambar merupakan faktor yang memegang peranan besar dalam menarik perhatian pembaca. Karena manusia memiliki kecenderungan untuk tertarik pada sesuatu melalui visual. Gray, Bounegru, dan Chambers (2012:134) menyatakan bahwa visual yang menarik selalu berhasil mencuri perhatian meskipun pada mulanya seseorang sedang tidak fokus. Sementara Francis M Dwyer dalam Pujiriyanto (2005:6) menggambarkan bahwa manusia belajar 1\% dilakukan melalui indera perasa, $1,5 \%$ melalui sentuhan, 3,5\% melalui penciuman, $11 \%$ melalui pendengaran dan $83 \%$ melalui penglihatan. Bahkan menurut Baugh dalam Azhar Arsyad (2009:10), hasil belajar seseorang yang didapat melalui indera pandang mencapai 90\%. Dengan perkembangan media dalam jaringan saat ini, menggunakan unsur visual merupakan salah satu strategi efektif untuk mendapatkan perhatian dari khalayak.

Poliklitik.com menggunakan kartun editorial sebagai bentuk praktik dari jurnalisme alternatif. Media ini mendobrak jurnalisme konvensional sebagai bentuk tandingan dari media arus utama. John Fiske dalam Chris Atton (1980) menunjukkan perbedaan antara media arus utama dan media alternatif dalam pemilihan berita mereka dan dalam cara pemilihan itu dibuat, http://jurnal.unpad.ac.id/kajian-jurnalisme 
175 | Kajian Jurnalisme

ISSN 2549-0559 (cetak) ISSN 2549-1946 (online)

Volume 01 Nomor 02 Tahun 2018

terutama bagaimana media alternatif mempolitisasi 'penindasan peristiwa' (meskipun Fiske sangat skeptis terhadap relevansi pers alternatif dengan masalah quotidian orang biasa). Ini tetap menjadi ciri yang menentukan dan terus-menerus tentang seberapa banyak media alternatif melihat pendekatan mereka terhadap konten mereka.

Dalam buku Alternative Media (1980: vii), Chris Atton menyatakan media alternatif dapat diartikan adalah

1. Media non-komersial, menunjukkan bahwa perhatian dasar untuk ide, bukan berorientasi keuntungan, dan tujuannya motivasi untuk publikasi.

2. Media dengan subjek publikasi mereka harus fokus pada "tanggung jawab sosial atau ekspresi kreatif, atau biasanya kombinasi keduanya".

3. Dapat juga cukup bagi pelakuknya untuk mendefinisikan diri mereka sebagai penerbit alternatif.

O'Sullivan di dalam buku yang sama juga mendefinisikan produksi independen (yang itu sendiri dapat ditafsirkan sebagai bagian dari media alternatif). Ia mencatat dua karakteristik lebih lanjut yang menetapkan praktik media alternatif selain dari arus utama: (1). proses produksi yang demokratis / kolektivis; dan (2). komitmen untuk inovasi atau eksperimen dalam bentuk dan / atau konten.

Poliklitik.com dapat diartikan kedalam media alternatif karena pertama, pengakuan dari penggiat media itu sendiri. Lewat wawancara dengan penulis Brodo Bilowo mengakui bahwa media mereka adalah media yang kontra terhadap media arus utama. Ia mengatakan media arus utama cenderung hanya menyajikan kerak-kerak permasalahan tanpa ada subtansi dan pesan bahkan tidak betanggung jawab terhadap khalayaknya. Kemudian Brodo juga mengatakan media mereka memiliki tujuan edukatif, bukan orientasi keuntungan. "Niatnya adalah media edukatif yang ingin para viewers-nya (anak muda) peduli terhadap masalah kebijakan publik, tapi kalau ujung-ujungnya butuh duit sih, masa kita mau tutup mata. Asalkan di jalan yang benar aja" Jelasnya menerangkan. Ia juga mengakui bahwa sampai saat ini untuk biaya operasional dan lain-lain masih dibiayai oleh Geomedia, meski ada pemasukan iklan dari website dan media sosial.

Dalam konteks ini Poliklitik.com dapat dikatakan sebagai media alternatif. Pertama media ini tidak berorientasi kepada keuntungan.Terlepas dari fakta bahwa Poliklitik.com tergabung dalam sebuah kelompok media, namun bukan termasuk dalam kelompok media besar (arus utama). Untuk proses produksi konten, Brodo mengakui tidak ada intervensi dari pemilik. Bahkan Geotimes sebuah portal berita yang juga tempat memuat karya-karya Poliklitik.com tidak memiliki pengaruh dalam produksi konten mereka. Kemudian mereka juga mengakui diri sebagai media dengan misi edukatif yang mencoba memberi influence dari pada sekedar menyampaikan informasi. Kemudian yang terakhir media ini berisi kebebasan berekspresi dalam berkreativitas. 


\section{Metode}

Metodologi adalah proses, prinsip, dan prosedur yang kita hunakan untuk mendekati problem dan mencari jawaban. Dengan kata lain, metodologi adalah suatu pendekatan umum untuk mengkaji topik penelitian. Metodologi bisa dipengaruhi arau berdasarkan perpektif teoretis yang digunakan utnuk melakukan penelitian, sementara perpektif teoretis adalah suatu kerangka penjelasan atau interpretasi yang memungkinkan peneliti memahami data dan menghubungkan data yang rumit dengan peristiwa dan situasi.

Menurut Creswell (2009, dalam Sugiyono 2013: 14-15) penelitian kualitiatif dibagi menjadi lima macam, yaitu fenomenologi (phenomenological research), teori Grounded (grounded theory), etnografi (ethography), studi kasus (case study) dan penelitian naratif (narrative research). Studi kasus sendii diartika oleh Creswell sebagai salah satu jenis penelitian kualitatif dimana peneliti melakukan ekplorasi secara mendalam terhadap program, kejadian, proses, aktivitas, terhadap satu orang atau lebih. Kasus yang iteliti terikat oleh waktu dan aktivitas. Pengumpulan data yang dilakukan oleh peneliti dengan menggunakan berbagai teknik pengumpulan data dan dalam waktu yang berkesinambungan.

Robert E. Stake membagi jenis studi kasus menjadi tiga yaitu:

1. Studi kasus intrinsik (intrinsic case study).

Jenis ini ditunjukan bagi peneliti yang ingi memahami sebuah kasus tertentu. Kasus yang diteliti dipilih bukan karena kasus terseut dapat mewakili kasus-kasus lain atau karena menggambarkan sifat maupun masalah tertentu melainkan karena dalam segala aspek kekhususkan dan kesederhanaannya kasus ini sendiri menarik perhatian dan minat peneliti. Sehingga tujuan dai studi kasus jenis ini bukan untuk memahami konstruk abstrak atau fenomena umum tertentu bukan untuk merumuskan suatu teori.

2. Studi kasus instrumental (instrumental case study).

Jenis studi kasus ini digunakan untuk meneliti suatu kasus dengan tujuan agar tersedia perspektif berkaitan dengan suatu isu atau perbaikan suatu teori. Dalam studi kasus instrumental, kasus yang diteliti bukanlah minat utama melainkan sebagai peran suportif guna mempermudah pemahaman tentang suatu yang lain. Kasus akan dicermati secara mendalam, menyeluruh, untuk mengunkap motif-motif eksternal dari suatu kasus.

\section{Studi kasus kolektif (collective case study).}

Jenis studi kasus kolektif bisa digunakan peneliti yang merasa kurang tertarik jika hanya mengkaji satu jenis kasus, peneliti juga dapat meneliti sejumlah kasus secara bersamaan untuk mengetahui fenomena, populasi, atau kondisi umum. Penelitian ini meupakan pengembangan 
177 | Kajian Jurnalisme

ISSN 2549-0559 (cetak) ISSN 2549-1946 (online)

Volume 01 Nomor 02 Tahun 2018

dari penelitian instrumental. Bisa jadi kasus-kasus individual bisa memperlihatkan suatu karakteristik umum bisa dicermati pola keberulangan dan keberagaman pesan.

Peneliti menggunakan studi kasus instrinsik Robert E. Stake karena dalam fenomena yang diteliti, bukan mewakili kasus-kasus lainnya. Kasus ini memiliki kekhususan dan kesederhanaannya sendiri. Kajian mengenai penggunaan kartun editorial oleh Poliklitik.com sebagai bentuk praktik jurnalisme alternatif, bukanlah mewakili praktik-praktik jurnalisme alternatif lainnya. Ditambah lagi dengan Poliklitik.com sebagai media yang menggunakan kartun editorial sebagai konten utama, merupakan kasus yang unik. Media ini tidak memiliki kompetitor yang serupa di Indonesia. Poliklitik.com adalah satu-satunya saat ini media massa yang menggunakan kartun editorial sebagai konten utama.

Oleh karena kekhususannya tersebut, peneliti menggunakan studi studi kasus intrinsik. Peneliti melihat masalah Poliklitik.com ini memiliki kunikan dan menarik perhatian peneliti. Sehingga peneliti perlu mengkaji bagaimana sebuah media yang memiliki kunikan dan kekhususan yang berbeda dari media pada umumnya melaksanakan kegiatan bermedia massa. Peneliti mengkaji bagaimana Poliklitik.com mengkonstruksi realitas berkegiatan media massa sebagai bentuk praktik jurnalisme alternatif.

\section{Hasil dan Pembahasan}

Awalnya sekitar tahun 2015, Brodo Bilowo menyampaikan niatnya untuk membuat media berkonsep ilustrasinya kepada seorang temannya yakni CEO Geo Media Group. Kebetulan mereka berjodoh dengan Geomedia yang mau memfasilitasi masalah domain dan Finanansial. Ia bermaksud untuk membuat sebuah media yang kritis namun menarik dan mudah dicerna oleh masyarakat. Untuk itu Brodo memanfaatkan kartun atau ilustrasi yang bersifat visual sebagai konten utama.

"Awalnya gue ngajuin untuk bikin media untuk sosial budaya politik, gua tawarin ke bos di Geomedia. Dia punya domain nganggur namanya Poliklitik. Jadi dikerjain langsung aja, Gue sendiri. Bos bayarin semua ongkos operasional termasuk biaya kontributor."

Geomedia Group adalah sebuah kelompok media yang berada di bawah badan hukum PT. Indonesia Milik Kita, GeoMedia Group merupakan kelompok usaha media yang berkembang sejak tahun 2011. Portfolio bisnis GeoMedia Group saat ini terdiri atas media cetak, media elektronik serta online. Visi dari kelompok media tersebut menjadi kelompok usaha media yang menjadi referensi bagi masyarakat Indonesia untuk mendapatkan informasi yang akurat dan terpercaya, tidak berpihak dan independen, mampu menyandingkan disiplin jurnalisme dan aktivisme sosial sekaligus berkontribusi bagi pemberdayaan masyarakat Indonesia.

http://jurnal.unpad.ac.id/kajian-jurnalisme 
Kajian Jurnalisme

ISSN 2549-0559 (cetak) ISSN 2549-1946 (online)

Volume 01 Nomor 02 Tahun 2018

Polilitik.com tergabung dalam kelompok group media tersebut serta difasilitasi dan dibiayai sepenuhnya oleh Geomedia Group ini. Beberapa media lain yang berada di bawah naungan Geomedia Group adalah Historia, Historia.id, TIMES, Geotimes, PARTV, I Channel, IniTV.net, IndonesiaTV, \#IniKpop dan Poliklitik.com itu sendiri. Konten-konten merekapun dipublikasikan juga di Geotimes.com melalui sebuah rubrik yang bernama kartun hari ini.

Media yang Ia ini rintis tersebut menyajikan berita/tajuk harian dalam bentuk kartun editorial. Media ini menjadikan kartun sebagai kekuatan utama mereka dengan mengunakan palform dalam jaringan sebagai medium distiribusi kepada khalayaknya. Alasan awal pembentukan media ini menurut Brodo Bilowo adanya kebosanan dengan konten dari media arus utama. Dia ingin membuat sebuah media dengan konten gambar yang dikemas secara satir dan sarkas, dan berita pendek sebagai faktor pendukung jurnalismenya itu sendiri.

Mengemas khalayak umum supaya lebih mudah jadi interest, ini apaan sih? Kok komiknya begini banget? Disini, oke kalau mau dibilangin masalah anak muda, kita majuinya apanih yang supaya anak muda ngga cuma terima berita yang sembarangan. Jadi mereka bisa mencerna lebih gampang, memilih berita yang menenangkan. Jadi lebih masuk kekoridor dimana lo berpolitik sehat. Arahnya sebenarnya kesitu.

Menurut Brodo Bilowo yang akrab dipanggil Ibod selaku penanggung jawab dari Poliklitik.com mengatakan bahwa media ini bertujuan menjaring anak-anak muda dengan target 18-24 tahun untuk meningkat kepedulian terhadap keadaan dan kondisi Indonesia. Mengharapakan munculnya anak-anak muda yang kritis dan kepedulian terhadap kebijakan publik. Ia menyatakan bahwa selama ini anak muda terkesan antipati terhadap hal-hal yang berhubungan politik.

Untuk itu ia menggunakan konsep konten kartun editorial sebagai penarik bagi segmentasi anak muda tersebut. Sekaligus karena Brodo memang selama ini bergelut di dunia ilustrasi sehingga Ia merasa perlu membuat sebuah media yang bisa menjadi pembeda dari media-media yang sudah ada. "Bedirinya Poliklitik.com dengan harapan meningkatkan public awarenness terhadap yang menyangkut kebijakan publik dengan kemasan humor supaya mudah dicerna untuk semua orang". Untuk itu lahirlah Poliklitik.com ini dengan konsep komik kritis (kartun editorial -red). Brodo bercerita bahwa saat itu mencita-citakan sebuah media berisikan karya yang dikemas secara satir dan sarkas kemudian diberi caption sebagai faktor pendukung jurnalisme. "Itu yang membuat kita menjadi sebuah media. Jadi bukan sekedar cuman lo mejengin karya doang" paparnya menjelaskan.

Poliklitik.com menggunakan platfoorm internet sebagai medium distribusi konten. Dengan perkembangan teknologi informasi, penggunaan platform internet dipercaya lebih sesuai dengan pasar dan khalayak saat ini. Khususnya untuk media yang mengutamakan konten karya visual. Poliklitik.com mengembangkan bentuk jurnalisme yang mengedepankan unsur visual denga memanfaatkan konten kartun editorial

http://jurnal.unpad.ac.id/kajian-jurnalisme 
179 | Kajian Jurnalisme

ISSN 2549-0559 (cetak) ISSN 2549-1946 (online)

Volume 01 Nomor 02 Tahun 2018

Poliklitik.com memuat isu-isu politik, sosial, dan ekonomi dalam bentuk karya-karya sarkas namun tetap bedasarkan riset dan fakta serta sumber yang kredibel dalam format media dalam jaringan. Polilitik.com menggunakan platform internet dengan alamat situs web www.Poliklitik.com. Menggunakan nama Poliklitik dengan penjelasan: "Poliklitik.com merupakan website ilustrasi mengenai isu-isu politik, sosial, dan budaya,dan dikemas secara humoris." Pada laman situs tersebut berisikan beberapa rubrik yakni, Kartun Hari ini, Wajah Politik, Bale Budaya, Politivi, dan Asal Kirim

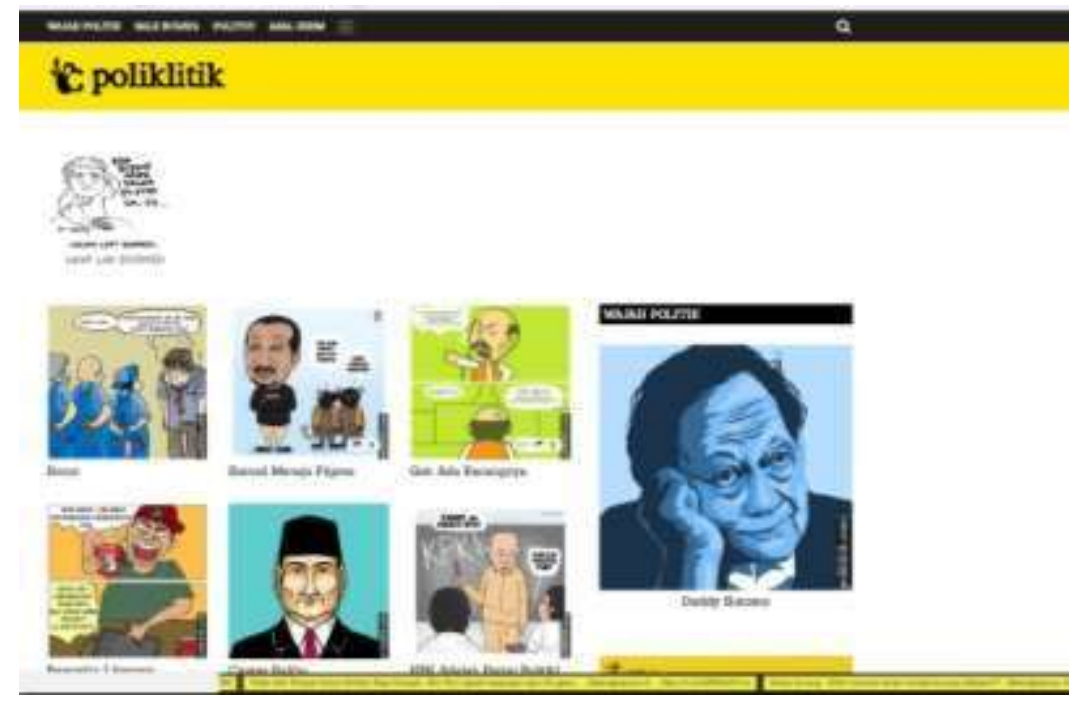

Gambar 3. Tampilan laman situs website Poliklitik.com Sumber: Poliklitik.com

Rubrik Kartun hari ini berisikan kartun editorial menyikapi fenomena-fenomena mengenai sosial, budaya, dan politik yang sedang hangat diperbincangakan. Kartun Hari Ini ditampilkan pada laman utama media ini. Berbentuk panel-panel yang berisikan sembilan karya kartun setiap lamannya. Kemudian rubrik Wajah Politik berisikan kartun/ karikatur yang menggambarkan orang-orang terkenal. Pada rubrik tersebut fokus memuat gambar-gambar orang terkenal seperti Politikus, pejabat, seniman, dan Publik figur lainnya.

Sebuah media untuk dapat berjalan dengan baik dan sebagaimana mestinya haruslah memiliki kebijakan-kebijakan yang mengatur orang-orang yang berada didalam sebuah organisasi tersebut. Namun dalam perjalanan media ilustrasi Poliklitik.com yang sudah berjalan selama kurang lebih tiga tahun ini tidak ketat dalam masalah kebijakan redaksi. Brodo Bilowo mengakui bahwa media mereka lebih cair dalam proses produksi dan sebagainya. Adanya keluesan dalam melakukan kegiatan produksi karena koordinasi bisa datang dari mana saja.

Misalnya dalam produksi karya oleh para kontributor. Brodo menjelaskan bahwa tidak terlalu mengarahkan kepada kontributor dalam memproduksi sebuah karya. Brodo menjelaskan 
bahwa redaksi tidak mengarahkan berita, atau tidak melalui proses pemilihan berita karena kontributor diberikan pandangan seluas-luasnya terhadap hal-hal dan berita yang menyangkut budaya, sosial dan politik, lalu dikirimkan ke editor untuk melalui proses kode etik jurnalisme. Walaupun pada praktiknya ada proses pelemparan isu dan sebagainya itu hanya tambahan referensi untuk para kontributor.

Sebenarnya kita tidak punya standar khusus. Kita coba lebih simple aja. Beberpa isu yang sedang hangat dan lagi hits, viral akhir-akhir ini. Itu kita coba pilah dan dipilih. Kemudian kita sampaikan ke kontributor. Ataupun kontributor punya isu yang menarik yang dia tangkap selama beberapa waktu teakhir. Akhirnya dibuat ilusrasinya, tapi yang paling penting adalah source-nya itu.

Namun ada tiga hal yang dipegang teguh oleh keredaksian Poliklitik.com yakni setiap karya (1) tidak boleh bermuatan yang menyinggung suku, agama, ras dan antara golongan (SARA), (2) tidak bermuatan pornografi, dan (3) tidak bermaksud untuk ujaran kebencian (hate speech).

"Ketika memilih isu kan sudah subjektif sebenarnya. Kita memilih isu yang ini atau kita tidak mau memilih isu yang itu kan sudah termasuk subjektivitas kita juga. Memang mau tidak mau kita harus katakan kita subjektif dalam pemilihan isu. Tapi ya tadi yang penting ngga SARA, ngga pornografi dan juga mencoba untuk berimbang juga. Kalau misalkan diilustrasinya atau menurut opininya kontributor atau ilustrator itu tone nya agak negatif. Kita coba menetralkan dengan caption-nya. Artinya kita coba untuk berimbang. Jaid teman-teman ataupun viewers yang melihat kalau bisa utuh gitu". 
181 | Kajian Jurnalisme

ISSN 2549-0559 (cetak) ISSN 2549-1946 (online)

Volume 01 Nomor 02 Tahun 2018

\begin{tabular}{|c|c|c|c|c|}
\hline $\begin{array}{c}\text { Linkungan Umum } \\
\text { a. Ekonomi } \\
\text { Kondisi ckonomi } \\
\text { yang terbilang stabil } \\
\text { dan menuju kearah } \\
\text { positif } \\
\text { b. Teknologi } \\
\text { Perkembangan } \\
\text { teknologi yang } \\
\text { semakin } \\
\text { menunjukan } \\
\text { pertambahan } \\
\text { pengguna internet } \\
\text { dan menyasar } \\
\text { berbagai kalangan } \\
\text { c. Politik } \\
\text { Kondisi politik } \\
\text { tersebut tidak } \\
\text { membatasi untuk } \\
\text { urusan industri } \\
\text { media } \\
\text { d. Sosial-budaya } \\
\text { Pola prilaku } \\
\text { masyarakat gaya } \\
\text { hidup digital native }\end{array}$ & $\begin{array}{l}\text { Lingkungan } \\
\text { Industri Media } \\
\text { a. Produk } \\
\text { Pengganti } \\
\text { Produk-produk } \\
\text { jurnaslitik baru } \\
\text { menggunakan } \\
\text { format video } \\
\text { animasi } \\
\text { b. Pendatang Baru } \\
\text { Akun-akun komik } \\
\text { dan kartun di } \\
\text { Instagram } \\
\text { c. Persaingan } \\
\text { Pelaku Bisnis yang } \\
\text { Sudah Ada } \\
\text { Kompas:id. } \\
\text { micecartoon.co,id, } \\
\text { inilahkartun, Komik } \\
\text { Jakarta } \\
\text { d. Kekuatan } \\
\text { Tawar Pemasok } \\
\text { Internet, listrik, dan } \\
\text { piranti keras seperti } \\
\text { komputer dan tablet } \\
\text { stylus, serta piranti } \\
\text { lunak (aplikasi) } \\
\text { untuk mengedit } \\
\text { Adobe Photoshop, } \\
\text { CorelDraw: dan } \\
\text { Adobe InDesign. } \\
\text { e. Kekuatan Tawar } \\
\text { Pembeli } \\
\text { Jumlah viewers dan } \\
\text { pengikut }\end{array}$ & $\underset{\substack{\text { Implementasi } \\
\text { Strategi }}}{\mid}$ & $\begin{array}{l}\text { Unit-unit Bisnis } \\
\text { a. Operasi } \\
\text { Pra produksi, } \\
\text { Produksi dan } \\
\text { Distribusi } \\
\text { b. Pemasaran } \\
\text { Diferensiasi Konten } \\
\text { dari media tain } \\
\text { c. Integrasi Lintas } \\
\text { Media } \\
\text { Geotimes.com } \\
\text { d. Penelitian dan } \\
\text { Pengembangan } \\
\text { Kelompok usahia } \\
\text { Geomedia Group } \\
\text { e. Keuangan } \\
\text { Kelompok usaha } \\
\text { Geomedia Group. } \\
\text { Adserse, } \\
\text { sponshorship,endor } \\
\text { sment, artikel } \\
\text { berbayar, paid } \\
\text { promote, jasa } \\
\text { ilustrasi } \\
\text { f. Sumber Daya } \\
\text { Manusia } \\
\text { Kartunis-kartunis } \\
\text { aktif di Instugram } \\
\text { g. Teknologi } \\
\text { Komputer dan } \\
\text { fablet snitus, serts } \\
\text { piranti lunak } \\
\text { (aplikasi) . Adobe } \\
\text { Photoshop, } \\
\text { CorelDraw; dan } \\
\text { Adobe InDesign. }\end{array}$ & $\begin{array}{l}\text { Struktur } \\
\text { Perusahaan } \\
\text { a. Integrasi } \\
\text { Kontrol Vertikal } \\
\text { - } \\
\text { b. Integrasi dan } \\
\text { Kontrol } \\
\text { Horizontal } \\
\text { Geo Media Group } \\
\text { PT. Indonesia Milik } \\
\text { Kita } \\
\text { c. Diversifikasi } \\
\text { Konten } \\
\text { Kartun editorial, } \\
\text { komik, karikatur, } \\
\text { dan ilustrasi } \\
\text { d. Diversifikasi } \\
\text { Pasar } \\
\text { - } \\
\text { e. Penyelarasan } \\
\text { Sumber Daya } \\
\text { - }\end{array}$ \\
\hline
\end{tabular}

Bagan 1. Formulasi dan Implementasi faktor internal dan ekternal Poliklitik.com berdasarkan kerangka analisis menajemen strategi media Sylvia M. Chan - Olmsted

Sumber: diolah oleh : Affandi (2019)

\section{Formulasi Strategi}

Pertumbuhan ekonomi pada tahun 2015 menunjukan kondisi yang cukup stabil untuk iklim usaha, tetapi tidak begitu signifikan. Melihat kondisi ekonomi yang terbilang stabil dan menuju kearah positif sehingga prospek menjalankan bisnis baru dirasa hal yang cukup aman. Kemudian, trend pada industri media yang sedang berkembang adalah ke arah digital (internet), media online dan start-up. Pada saat ini hal tersebut memiliki potensi besar untuk dapat berjalan dan berkembang. Dari aspek ekonomi tersebut, Poliklitik.com dapat mengambil peluang dan resiko yang ada untuk memulai menjalankan bisnis media sesuai yang mereka harapkan. 
Sedangkan pada aspek teknologi, dapat dikatakan sangat menguntungkan untuk memulai bisnis, sebab teknologi sudah semakin memudahkan dalam berbagai hal baik untuk produsennya, konsumen maupun pengiklan. Perkembangan teknologi informasi mempengaruhi dalam proses pra-produksi, produksi, distribusi dan pasca-produksi. Untuk media yang menggunakan teknologi informasi dalam aktivitas sehari-harinya maka perkembangan teknologi ini menjadi modal besar untuk Poliklitik.com. Selain memudahkan Poliklitik.com selaku produsen, teknologi informasi saat ini juga memudahkan khalayak untuk lebih mudah mengakses konten Poliklitik.com karena sudah dalam platform dgital dan online. Selain itu juga mendekatkan produsen dengan pelanggannya. Oleh karen itu, untuk aspek teknologi informasi dirasa sangat berdampak positif untuk Poliklitik.com dalam menjalankan bisnis medianya.

Ditelisik dari aspek politik, kebijakan pemerintah terhadap pers di Indonesia sudah tidak lagi otoriter dan mengekang. Kebebasan pers semenjak reformasi hingga saat ini dirasa sudah mengalami perbaikan walaupun masih ada cela dibeberapa sisi. Poliklitik.com sebagai sebuah media yang cukup aktif dalam menyampaikan kritik kepada pemerintah tidak mengalami permasalahan berarti dalam hal kebijakan dan lain-lain. Selain itu Presiden Joko Widodo mendukung penuh industri digital yang berbasiskan online lewat beberapa kebijakannya. Hal ini memberi dampak positif terhadap Poliklitik.com dalam menjalanakan dan mengembangkan medianya.

Dalam aspek sosial budaya, kecendrungan perilaku masyrakat sudah mengarah keaktivitas yang serba digital. Pola perilaku masyarakat sudah tidak asing lagi dengan gawai dan internet. Pola perilaku tersebut mempengaruhi cara masyarakat dalam mengakses informasi. Sehingga dalam konteks sosial budaya ini merupakan faktor positif untuk Polikltik.com.

Tabel 1. Faktor Ekstenal Lingkungan Umum Poliklitik.com

\begin{tabular}{|c|c|c|c|}
\hline Lingkungan Umum & Positif & Netral & Negatif \\
\hline Ekonomi & $\sqrt{ }$ & & \\
\hline Teknologi & $\sqrt{ }$ & & \\
\hline Politik & $\sqrt{ }$ & & \\
\hline Sosial-budaya & $\sqrt{ }$ & & \\
\hline
\end{tabular}

Sumber : diolah dari : Affandi (2018)

Kolaborasi dari keempat aspek pada tabel di atas menunjukan tanda positif. Hal tersebut mengindikasikan kodisi lingkungan umum yang positif sebagai faktor eksternal yang mempengaruhi formulasi stratefi manajemen media Poliklitik.com. Dengan lingkungan umum 
183 | Kajian Jurnalisme

ISSN 2549-0559 (cetak) ISSN 2549-1946 (online)

Volume 01 Nomor 02 Tahun 2018

yang positif tersebut Poliklitik.com dapat mengembangkan medianya dan sumberdaya yang mereka miliki.

Tabel 2. Faktor Ekstenal Lingkungan Industri Media Poliklitik.com

\begin{tabular}{|l|l|l|l|}
\hline Linkungan Industri Media & Tinggi & Sedang & Rendah \\
\hline $\begin{array}{l}\text { Ancaman dari Produk-produk } \\
\text { Pengganti }\end{array}$ & & $\sqrt{ }$ & \\
\hline Acaman Pendatang Baru & & $\sqrt{ }$ & \\
\hline $\begin{array}{l}\text { Persaingan Pelaku Bisnis yang } \\
\text { Sudah Ada }\end{array}$ & $\sqrt{ }$ & & \\
\hline $\begin{array}{l}\text { Kekuatan Tawar dari Pemasok } \\
\text { Kekuatan Tawar dari } \\
\text { Konsumen, Pelanggan, atau } \\
\text { Pembeli }\end{array}$ & $\sqrt{ }$ & & \\
\hline
\end{tabular}

Sumber : diolah dari : Affandi (2018)

Berdasarkan tabel analisis di atas, menunjukan Poliklitik.com medapat persaingan yang cukup ketat dalam industri media massa. Sebagai media baru dengan konsep yang sangat berbeda dengan media arus utama menyebabkan Poliklitik.com harus menarik khalayak sedikitdemi-sedikit untuk memperkenalkan konten dan medianya. Namun dengan segmentasi dan konten yang identik tersebut juga menjadi kekuatan utama bagi Poliklitik.com dalam persaingan media massa. Diferensiasi tersebut membuat Poliklitik.com memiliki pengikutnya tersendiri.

Aspek produk pengganti memang menjadi salah satu ancaman yang cukup berarti sebagai media yang memanfaatkan kemajuan teknologi. Seiring perkembangan teknologi berbagai macam produk baru silih berganti hilir mudik menghiasi produk-produk media massa. Produk pengganti yang menjadi ancaman sebagai produk pengganti adalah video animasi dengan platform Youtube sebagai medium. Sebab Youtube menurut survei yang dilakukan oleh Wearesocial.com merupakan platform sosial media yang paling sering digunakan masyarakat Indonesia. Kemudian di iringi Facebook dan Instagram. Oleh karena itu Poliklitik.com menguatkan distribusi kontennya lewat media sosial terutama Instagram. Selain itu Poliklitik.com juga menguatkan konten mereka dengan pesan-pesan kritis dan skeptis dengan pembahasan menuju ke substansi permasalahan. Sebagai kontra media arus utama yang sekedar menyajikan informasi. Sehigga dapat disimpulkan ancaman dari produk-produk pengganti berada pada zona sedang. 
Kajian Jurnalisme

ISSN 2549-0559 (cetak) ISSN 2549-1946 (online)

Volume 01 Nomor 02 Tahun 2018

Sementara ancaman dari pendatang baru dengan konten serupa dengan Poliklitik.com berdasarkan tabel dan penjelasan di atas menunjukan tensi yang rendah. Sebagai media dengan konsep kartun editorial yang bersifat kritis dan edukatif, serta pesan-pesan sarkastik Poliklitik.com belum memiliki pesaing utama dengan konsep yang sama. Di sisi lain kontenkonten kartun sebenarnya sudah menjamur dan menjadi salah satu trend di media sosial. Namun belum ada yang berani membuat sebuah media yang serius mengangkat isu-isu politik, sosial dan budaya yang sedang berkembang. Pesaing-pesaing baru tersebut masih bersifat perseorangan dan tidak berfokus kepada masalah kepentingan umum. Untuk itu ancaman adanya pendatang baru dapat dikatakan rendah namun memiliki potensi yang sedang jika kedepannya pendatang baru terebut berani untuk mengambil sisi-sisi idealis sebagai media massa jurnalistik.

Adapun aspek persaingan dengan pelaku bisnis yang sudah ada dapat dikatakan memiliki tensi yang tinggi. Persaingan media massa di Indonesia masih dikuasai oleh mediamedia yang tergabung dalam kelompok media arus utama. Sehinga menyebabkan perkembangan media baru dan tersegmentasi seperti Poliklitik.com dapat dikatakan lambat. Tingginya persaingan pelaku bisnis yang sudah ada juga merambah pada aspek-aspek kebaruan. Sebab media-media arus utama juga menggunakan berbagai platform untuk menyalurkan konten-konten mereka. Diperparah dengan integrasi dan konglomerasi media yang memiliki modal dan kekuatan yang besar. Tensi tinggi dalam persaingan pelaku bisnis yang sudah ada ini menyebabkan lambatnya Poliklitik.com dalam merambah khalayak yang lebih luas.

Dikaji dari kekuatan penyuplai atau pemasok sebagai sumber bahan baku dalam memproduksi konten terbulang tinggi. Sebab penyuplai utama media-media digital adalah teknologi informasi yang semakin mudah diakses. Bahan baku untuk konten-konten Poliklitik.com ada informasi-informasi yang dapat diakses dengan mudah oleh siapa saja dan dimana saja. Sehinga kekuatan penyuplai bahan-bahan baku yang untuk diproduksi Poliklitik.com menjadi sebuah konten yang memiliki nilai tambah kritis dan edukatif serta menarik adalah tinggi.

Berdasarkan tabel dan penjelasan sebelumnya, Poliklitik.com di untungkan dengan adanya pembeli dan khalayak. Pembeli dan khalayak diartikan sebagai viewers Poliklitik.com baik di laman resmi ataupun media sosial. Khalayak Poliklitik.com adalah pengikut yang kritis dan terbuka. Aktifnya pengikut Poliklitik.com dapat dilihat dari aktif memberikan feedback baik berupa like dan komentar. Sehingga tujuan dari Poliklitik.com sebagai influencer bagi kahlayak agar menjadi masyarakat yang kritis dan skeptis dapat terwujud. Hal tersebut menjadi kekuatan tersendiri bagi media kartun editorial Poliklitik.com ini.

Dalam proses formulasi strategi Poliklitik.com harus bisa melihat peluang yang ada dari faktor eksternal dan menggabungkan dengan kekuatan dari aspek internal Poliklitik.com. Dalam faktor eksternal, Kondisi perekonomian yang cendrung stabil, kemajuan teknologi yang http://jurnal.unpad.ac.id/kajian-jurnalisme 
185 | Kajian Jurnalisme

ISSN 2549-0559 (cetak) ISSN 2549-1946 (online)

Volume 01 Nomor 02 Tahun 2018

memudahkan, kondisi politik yang bebas dalam berekspresi, serta kebutuhan informasi selain media arus utama menjadi peluang untuk Poliklitik.com dalam menjalan sebuah media kartun editorial dalam dalam jaringan. Hal tersebut diperkuat oleh kondisi internal berbentuk diferensiasi konten dari media lainnya yakni bentuk kartun, kekuatan pesan, sumber daya manusia, teknologi serta integrasi lintas media. Kombinasi faktor internal dan eksternal dari Poliklitik.com tersebut melahir strategi penggunaan kartun editorial sebagai konten utama Poliklitik.com yang bersifat kritis, sarkas dan edukatif. Hal tersebut merupakan bentuk formulasi dari tujuan Poliklitik.com yang ingin menjadi media kritis, sarkas, dan edukatif sebagai influencer bagi khalayaknya agar dapat kritis dan skeptis dalam menanggapi isu-isu tentang kebijakan publik yang sedang aktual terjadi.

Kemudian dalam menyalurkan konten-konten agar dapat mendapat perhatian dan khalayak yang lebih luas degan perilaku digital native dan perkembangan teknologi yang menggunakan platform intenet. Kemudian ditambah dengan kekuatan internal dengan bentuk konten kartun yang meruapakan karya visual yang menarik perhatian, kemampuan personel yang mumpuni, teknologi yang memudahakan. Kombinasi tersebut melahirkan formulasi strategi Poliklitik.com yakni memanfaatkan platform internet dan media sosial sebagai penyalur konten.

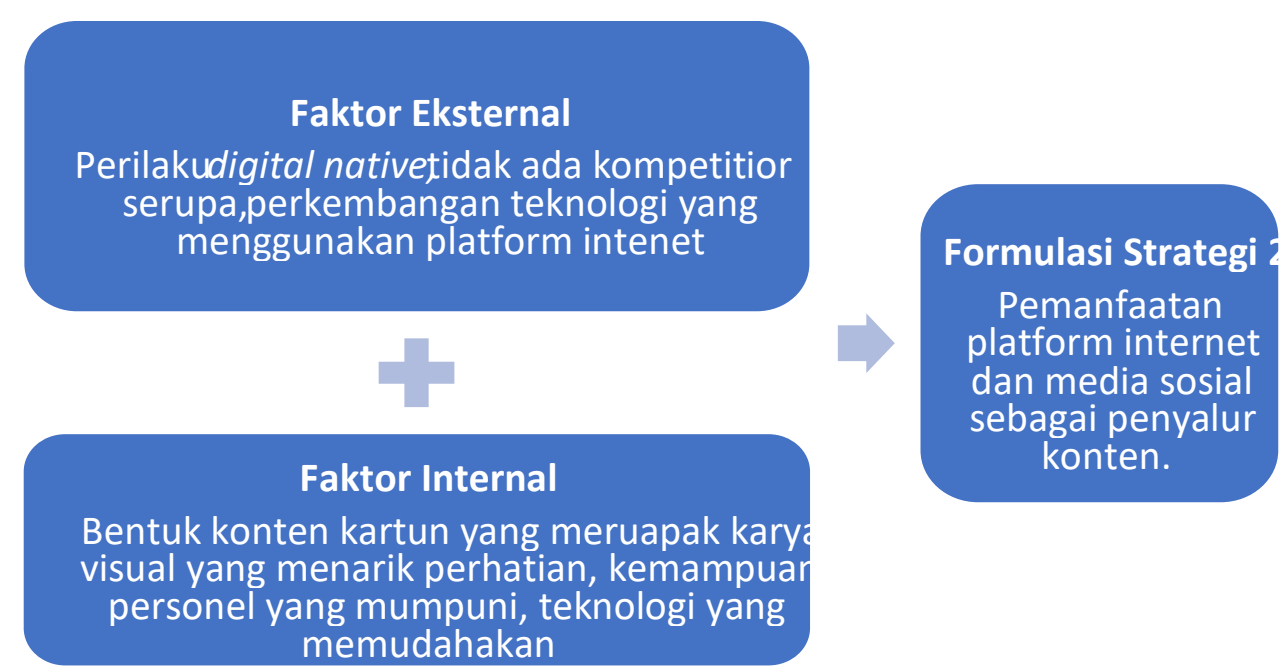

Bagan 2. Formulasi Strategi 2 Poliklitik..com
Sumber: Peneliti

http://jurnal.unpad.ac.id/kajian-jurnalisme 
Berdasarkan pemaparan tersebut, maka formulasi strategi Poliklitik.com yakni Penggunaan kartun editorial sebagai konten utama Poliklitik.com yang bersifat kritis, sarkas dan edukatif

Menggunakan konten kartun editorial yang menarik perthatian dengan pesan yang kritis, sarkas dan edukatif sesuai dengan tujuan Poliklitik.com yang ingin menjadi media kritis, sarkas, dan edukatif sebagai influencer bagi khalayaknya agar dapat kritis dan skeptis dalam menanggapi isu-isu tentang kebijakan publik yang sedang aktual terjadi.

Dalam tulisannya, Chriss Atton menjelaskan situasi apa saja yang dipenuhi sehingga sebuah media dikatakan sebagai media alternatif. Hal tersebut karena banyak paraktik yang bisa dimasukan keadalah kategori jurnalisme alternatif. Dalam jurnalisme alternatif, ada kesamaan dalam praktik dan banyak pula perbedaan dengan praktik jurnalisme pada umumnya. Atton bahkan menyontohkan dalam jurnalisme alternatif orang bisa menulis berita tentang irinya sendiri atau warga biasa lainnya, bukan orang besar, orang pentung atau pejabat politik., tentnag kehidupan sehari-harinya, dan itu adalah nilai berita bagi mereka.

Untuk itu ada tiga kondisi yang dijelaskan oleh Chriss Atton dalam tulisannya:

1. Tidak berorientasi keuntungan

Dalam poin ini Atton menjelskan jika media alternatif adalah sebuah ferakan yang menjatuhkan kaum borjuis di Prancis dengan menggunakan media alternatif. Pada dasarnya media tersebut memiliki tujuan tertentu, yang hadir untuk mencapai tujuannya tapi bukanlah mencari kuntungan semata. Kemunculannyapun merupakan kontra hegemoni dari media arus utama. Sebagai dari bentuk antitesis dari jurnalisme yang sudah ada selama ini. Polikltik.com memiliki misi untuk menarik anak-anak muda yang mereka nilai saat ini apatis terhadapa kondisi dan kebijakan publik. Sehingga mereka merancang sebuah media yang menarik dan mudah dicerna oleh kahlayak umum (anak muda) agar dapat lebih peka terhadap masalah-masalah yang saat ini sedang terjadi.

Di lain hal Brodo dalam menjalankan media ini masih bergantung secara finansial kepada kelompok media yang menaungi mereka, yakni Geomedia group. Sampai saat ini media ini masih dibiayai sepenuhnya oleh kelompok media tersebut. Walaupun Poliklitik.com sudah mendapatkan pendapatan dari iklan, adsence, endorse di Instagram dan sebagai macam. Namun hal tersebut tidak cukup untuk ememnuhi biaya operasional dan gaji karyawan dan insentif kontributor. Maka Brodo mengakui sendiri jika media mereka masih ketergantungan dengan kelompok medianya.

"Meskipun niat kita adalah media yang basiknya edukasi, tapi kalau ujungujungnya butuh duit sih masa kita mau tutup mata. Asal di jalan yang benar aja".

Namun demikian dalam tiga tahun perjalanan Poliklitik.com yang menyatakan tidak berorientasi kepada keuntungan, memang karena sejauh ini keuntungan yang mereka http://jurnal.unpad.ac.id/kajian-jurnalisme 
187 | Kajian Jurnalisme

ISSN 2549-0559 (cetak) ISSN 2549-1946 (online)

Volume 01 Nomor 02 Tahun 2018

dapatkan secara materil termasuk sedikit. Karena sejauh ini masih bergantung kepada kelompok usaha GeoMedia Group.

2. Berfokus kepada tanggung jawab sosial atau eksresif kreatif, atau kombinasi

Keduanya Dengan dasar media yang tidak berfokus kepada keuntungan maka alternatif disini diartikan sebagai bentuk dari tujuan media yang berbasiskan nilai-nilai tanggung jawab sosial akibat ketidak kepercayaan terhadap media arus utama. Poin pertama yakni berfokus kepada tanggung jawab sosial. Pada aspek ini Poliklitik.com dalam wawancara peneliti bersama Brodo menyatakan bahwa media ini bertujuan sebagai influencer untuk anak muda agar peduli terhadap kebijakan publik dan bisa bersikap kritis dan skeptis. Sebab Ia merasa bahwa saat ini banyak anak muda yang antipati terhadap masalah-masalah politik dan kebijakan publik. Untuk itu perlu kiranya membuat sebuah media yang menarik untuk anak muda. Selain itu juga menjadi media yang bisa menjadi alternatif bagi para pembaca supaya tidak termakan mentah oleh pemberitaan media arus utama. Pernyataan tersebut yang dapat kategorikan bahwa Poliklitik.com adalah sebuah media alternatif yang berfokus kepada tanggung jawab sosial.

Dalam observasi virtual yang peneliti lakukan terhadap website dan media sosial Poliklitik.com kebanyak isu yang diangkat oleh Poliklitik.com disadur dari media-media arus utama. Hal tersebut menjadi kontradiksi saat Poliklitik.com menyatakan jika kontenkonten media arus utama saat ini mengutamakan kecepatan daripada subtansi yang terkandung dalam suatu peristiwa. kemudian juga dalam karya-karya dan tulisan yang dipublikasikan oleh Poliklitik.com belum menunjukkan mereka mengkaji peristiwa lebih dalam mengenai substansi permasalahan. Masih berada pada permukaan peristiwa dengan selipan bumbu-bumbu sarkas.

Poin kedua yakni aspek ekspresi kreatif. . Diartikan dengan media yang melunturkan batasan-batasan yang jurnalisme konvensional selama ini. Bentuk dari kebebasan berekspresi dengan menggunakan cara-cara kreatif yang berbeda dari sebelumnya. Brodo bilowo memutuskan membuat Poliklitik.com dengan konsep menggunakan konten visual.

3. Pelakunya menyatakan diri sebagai bentuk dari jurnalisme alternatif

Poliklitik.com dapat diartikan kedalam media alternatif karena pertama, pengakuan dari penggiat media itu sendiri. Lewat wawancara dengan penulis Brodo Bilowo mengakui bahwa media mereka adalah media yang kontra terhadap medai arus utama yang hanya menyajika kerak-kerak permasalahan tanpa ada subtansi dan pesan bahkan tidak betanggung jawab terhadap khalayaknya.

http://jurnal.unpad.ac.id/kajian-jurnalisme 
"Karena ada yang bilang poliklitik tidak punya kelamin nih. Maksudnya lo ngga memihak siapapun. Justru itu yang kita pengen. Lo nerusaha untuk netral, itu kan udah pakemnya dan seharusnya kita berada di posisi netral. Dan ada juga kemasankemasan sarkas yang keliatannya kita bersekutu dengan kubu tertentu padahal sebenarnya itu sebuah satir. Itu yang bikin follower poliklitik itu unik. Mereka kebawa, Gua harus netral, gua melihat isu ini harus netral bukan sekadar melihat luarnya saja".

Brodo Bilowo mengungkapkan kegelisahannya terhadap situasi dan kondisi bermedia di indonesia saat ini. Banyak pembaca media yang mudah tergoreng oleh isu yang masih di permukaan. Tetapi banyak yang tidak menyentuh subtansi apa yang sebenarnya mengakar pada suatu peristiwa atau berita tersebut. Untuk itu dia membuat Poliklitik.com sebagai bentuk dari penyaluran kegelisahannya melihat kondisi bermedia saat ini.

Berdasarkan ketiga situasi tersebut, apakah Poliklitik.com dapat disebut melakukan praktik jurnalisme alternatif? Seperti yang telah dijabarkan diatas, bahwa Poliklitik.com memenuhi ketiga kriteria pelaku jurnalisme alternatif. Adapun Poliklitik.com tergabung dalam kelompok media usaha Geo Media Group, namun kelompok usaha media tersebut bukanlah termasuk dalam kategori kelompok media arus utama. Hal tersebut tidak mengurangi bahwa Poliklitik.com melakukan kegiatan jurnaslime alternatif sesuai tiga kategori yang telah dijelaskan sebelumnya.

\section{Simpulan dan Saran}

Poliklitik.com lahir sebagai sebuah media alternatif yang menyasar segementasi anak muda karena kecewa denan konten yang disasjikan oleh media arus utama. Media ini menggunakan konten kartun editorial yang bersifat kritis dan edukatif agar menarik perhatian khalayak. Poliklitik.com bertujuan menjadi Influencer bagi anak muda agar lebih kritis dan skeptis dalam menanggapi isu yang sedang aktual.

Manajemen strategi media yang dibetuk Poliklitik.com adalah dengan menggunakan kartun editorial sebagai koten utama. Selanjutnya dengan penggunaan media sosial sebagai medium distribusi konten untuk menyasar khalayak anak muda. Namun Poliklitik belum sanggup bersaing di industri media di Indonesia, karena masih dalam tahapan bertahan dan berkembang di industri media Indonesia.

Poliklitik.com sudah menggunakan kaidah-kaidah jurnalistik agar menjadi jurnalisme berkaualitas, terutama kaidah penyajian dalam bentuk menarik. Sebab Poliklitik.com menyajikan konten dalam bentuk gambar kartun editorial yang menarik secara visual dan berisikan pesan-pesan sarkas yang bersifat kritis. Sementara proses penggarapan isu yang dilakukan oleh Poliklitik.com masih berkutat pada permukaan masalah bukan pada subtansi masalah seperti yang Poliklitik.com cita-citakan. Hal tersebut terjadi dikarena Poliklitik.com menggunakan teknik kurasi dan agregasi dalam proses produksi konten mereka. 
189 | Kajian Jurnalisme

ISSN 2549-0559 (cetak) ISSN 2549-1946 (online)

Volume 01 Nomor 02 Tahun 2018

Poliklitik.com melakukan produksi konten menggunakan praktik jurnalisme kurasi dan agregasi yang menyebabkan ketergantungan dengan isu-isu yang dihadirkan media arus utama. Hal tersebut menjadi kontradiksi bagi Poliklitik.com sebagai media alternatif yang notabenenya kontra hegemoni media arus utama. Untuk meningkatkan kualitas jurnalisme yang dihasilkan, sebaiknya Poliklitik.com melakukan liputan atau verifikasi lebih mendalam kepada sumbersumber dari berbagai pihak.

Poliklitik.com memantapkan diri sebagai media alternatif sebagai bentuk tandingan dari konten-konten yang dihasilkan oleh media arus utama. Jalur alternatif terlahir dari sebuah kegelisahan terhadap konten media arus utama yang cenderung sama, berkutat pada permukaan permasalahan serta mengutamakan kecepatan. Oleh karena alasan pembentukan Poliklitik.com tersebut, maka sudah seharusnya konsisten dengan praktik jurnalisme alternatif yang notabenenya tandingan dari kuasa media dominan sehingga Poliklitik.com tidak terjebak dalam pusaran media arus utama.

\section{Daftar Pustaka}

Albarran, Alan B. 2006. Handbook of Media Management and Economics. New Jersey: Lawrence Erlbaum Associates

Atton, Chriss. 2002. Alternative Media. London: Sage Publications. Inc. Sage Publications. Inc

Bungin, Burhan. 2007. Penelitian Kualitatif, Komunikasi, Ekonomi, Kebijakan Publik, dan Ilmu Sosial lainnya. Jakarta: Kencana Prenada Media Group.

Creswell, J.W. 1998. Qualitative inquiry and research design: Choosing among five traditions. Thousand Oaks, CA: Sage Publications. Inc.

Kuswarno, Engkus. 2009. Metode Penelitian Komunikasi : Fenomenologi, Konsepsi, Pedoman dan Contoh Penelitiannya, Widya Padjajaran, Perpustakaan Pusat UII

Lim, M. 2012. The League of Thirteen: Media Concentration in Indonesia. Research report. Tempe, AZ: Participatory Media Lab at Arizona State University.

Mc Quail, Dennis. 2000. Mc Quail's Communication Theory (4th Edition). London: Sage Publications

Mulyana, Deddy. 2008. Metode Penelitian Kualitatif: Paradigma Baru IIlmu Komunikasi dan Ilmu Sosial Lainnya. Bandung: PT. Remaja Rosdakarya.

Pr., Subagyo. 1981. "Prakata”, Pramono: Karikatur-Karikatur 1970-1981. Jakarta: Penerbit Sinar Harapan

Pramono. 1996. Kartun Bukan Sekedar Benda Seni, Prisma, Jakarta.

Pujiriyanto. 2005. Desain Grafis Komputer, Penerbit Andi. Yogyakarta Sobur, Alex.

2004. Semiotika Komunikasi. Bandung: Remaja Rosdakarya

Stake, Robert E. 2005. The Art of Case Study. London: SAGE Publication, Inc.

http://jurnal.unpad.ac.id/kajian-jurnalisme 